\title{
Inflation in Tajikistan: \\ Forecasting Analysis and Monetary Policy \\ Challenges
}

Fahad Alturki and Svetlana Vtyurina 


\title{
IMF Working Paper
}

\author{
Middle East and Central Asia Department \\ Inflation in Tajikistan: \\ Forecasting Analysis and Monetary Policy Challenges \\ Prepared by Fahad Alturki and Svetlana Vtyurina \\ Authorized for distribution by Axel Schimmelpfennig ${ }^{1}$
}

January 7, 2010

\begin{abstract}

\section{This Working Paper should not be reported as representing the views of the IMF.} The views expressed in this Working Paper are those of the author(s) and do not necessarily represent those of the IMF or IMF policy. Working Papers describe research in progress by the author(s) and are published to elicit comments and to further debate.

This paper attempts to explain short- and long-term dynamics of - and forecast - inflation in Tajikistan using the Vector Error Correction Model (VECM) and Autoregressive Moving Average Model (ARMA). By analyzing different transmission channels through the VECM, we were able to evaluate their relative dominance, magnitude, and speed of transition to the equilibrium price level, with the view of identifying those policy tools that will enhance the effectiveness of monetary policy. We found that excess supply of broad money is inflationary in both the short and long term. The dynamic analysis also demonstrates that the exchange rate and international inflation have a strong impact on local prices. Available monetary instruments, such as the refinancing rate, have proven to be ineffective. Therefore, the Tajik monetary authority could greatly benefit from enhancing its monetary instruments toolkit, including by developing the interest rate channel, to improve its monetary policy execution and to achieve stable inflationary conditions.
\end{abstract}

JEL Classification Numbers: E31, E37, E41, F31, C32, O53

Keywords: monetary policy, money demand, inflation, dollarization, cointegration, error correction model, forecasting, autoregressive moving average model, Tajikistan

Authors’ E-Mail Addresses: falturki@sama.org.sa; svtyurina@imf.org

\footnotetext{
${ }^{1}$ The authors thank David Owen and Axel Schimmelpfennig for valuable comments, and Christine Ebrahimzadeh and $\mathrm{Ai}$ Kato for editorial assistance.
} 


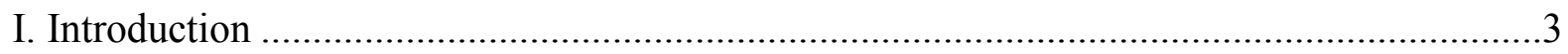

II. Monetary Policy Transmission Channels in Tajikistan..............................................4

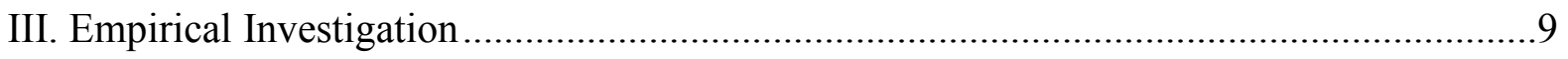

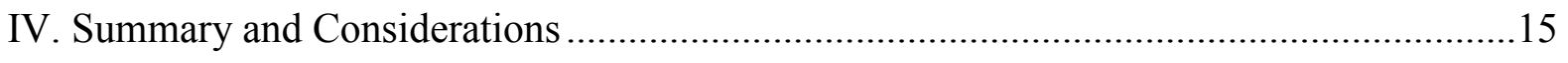

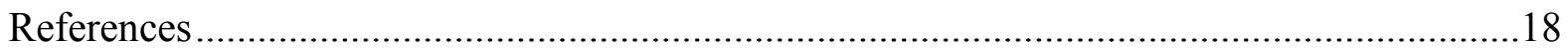

Tables

Table 1. Augmented Dickey-Fuller Unit Root Tests .........................................................8

Table 2. Johansen Co-Integration Tests ..........................................................................9

Table 3. Model Restriction and Weak Exogeneity Tests.................................................. 10

Table 4. Main Statistics of Various ARMA Models, 1999-2009.......................................13

Exhibits and Figures

Exhibit 1. Monetary Policy Transmission Mechanism in Tajikistan.....................................

1. NBT Refinancing Rate and Bank Lending Rates, 2001-08 ..............................................5

2. Money Growth and Inflation, 2001-08 ...................................................................5

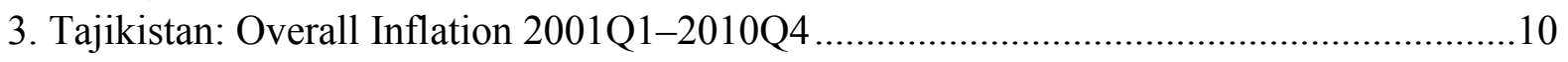

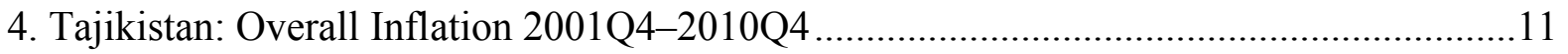

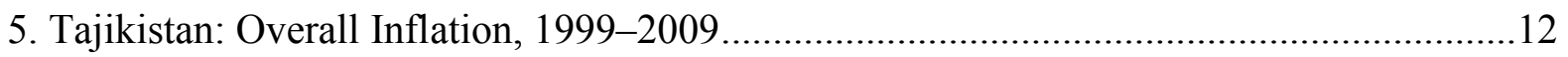

6. Tajikistan: Inflation Forecast Based on BARMA (2,2) Model, Dec. 2007-June 2009.......14

7. Tajikistan: Inflation Forecast Based on ARMA (2,2) Model, Dec. 2008-Dec. 2010 .........14 


\section{INTRODUCTION}

Similar to many other countries of the former Soviet Union, Tajikistan has undergone a period of very high inflation during its transition period starting in 1991. Years of civil war (1992-97) have further complicated macroeconomic management and limited the authorities' ability to develop a monetary policy framework and instruments necessary for controlling inflation. The end of civil strife and resumption of stability were followed by improvements in monetary policy management, yet much is still to be achieved in this area. In addition to weaknesses in monetary policy management, other culprits contributed to the difficulties in controlling inflation, such as a high level of dollarization, continuation of provision of directed credits to special sectors, a low level of financial intermediation, and underdeveloped financial markets.

Given elevated poverty levels in Tajikistan, high inflation negatively affects the purchasing power of the population, and hurts the most vulnerable groups especially. To prevent inflation from reaching detrimental levels, it would be beneficial to strengthen the monetary policy framework. In this vein, our paper attempts to explain inflation dynamics and forecast inflation using the Vector Error Correction Model (VECM). We then employ the Autoregressive Moving Average Model (ARMA) to compare our inflation estimates. One caveat needs to be mentioned: for a country like Tajikistan, because of the lack of data and potential instability in structural parameters, it is difficult to make forecasts by applying conventional models. To balance the trade-off between testing a sample size that should be large enough to apply (asymptotic) econometrics, and the need to address statistical problems associated with structural changes, our paper uses monthly and quarterly data starting January 2001. The results demonstrate that the nominal exchange rate and, to a lesser extent, interest rate channels exert influence on prices. Based on our findings, we encourage the authorities to improve their policy toolkit by strengthening the interest rate channel, making reserve requirements an effective instrument, resuming operations with tradable securities, and fostering financial deepening.

This paper is organized as follows. Section II briefly describes the main features of the monetary policy transmission mechanism and its relevance for policymaking. Section III presents the results of the VECM and ARMA models. Section IV discusses broad policy considerations to improve monetary policy effectiveness. 


\section{Monetary Policy Transmission Channels in Tajikistan}

The monetary transmission mechanism is the process by which changes in the money supply influence the amount that private economic agents wish to spend on goods and services (Mankiw, 1992). A shallow financial market, provision of directed credits, a low level of monetization $^{2}$, and a high level of dollarization in Tajikistan, render somewhat futile the examination of wealth and monetarist channels - major channels that are distinguished in literature and present in developed economies. This conclusion is in line with findings of other research on transition countries (Horvath and Maino, 2006, Dabla-Norris and Floerkemeier, 2006). In this analysis, therefore, only four transmission channels are examined (money supply, income, and interest and exchange rates) as all should be operational in a small open (market) economy, such as Tajikistan (Exhibit 1).

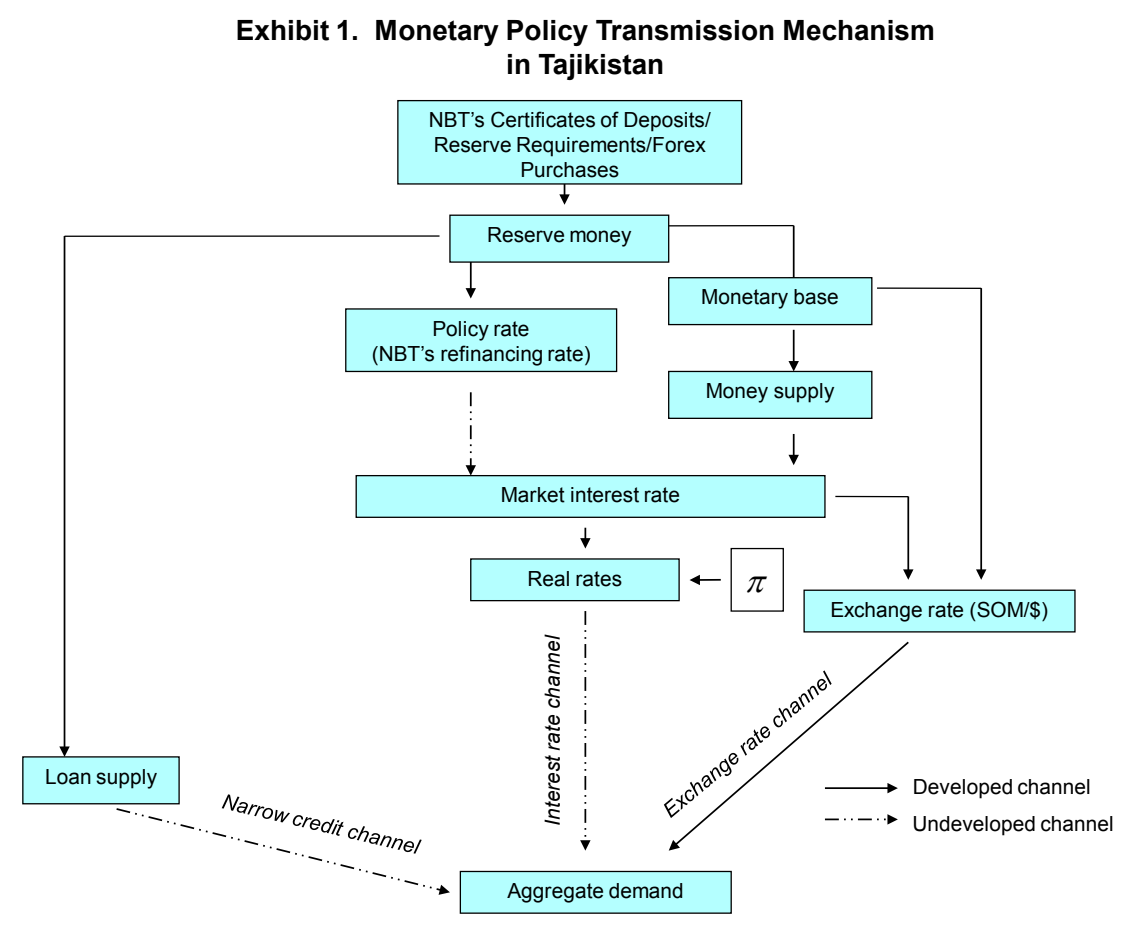

Examining the money channel could help shed light on the relationship between money supply and inflation. This relationship has not been at all straightforward in other transition economies. In Russia, for instance, during several episodes over the past decade, inflation fell while money growth accelerated significantly. ${ }^{3}$ As demonstrated in Figure 1, a similar phenomenon is observed in Tajikistan, as decoupling between inflation and money growth seems to occur from 2003 to 2004, while the relationship becomes as expected since 2005 .

\footnotetext{
${ }^{2}$ The monetization of the economy — broad money to GDP—remains relatively low (18 percent of GDP in 2009), reflecting the lingering impact of civil war and hyperinflation.

${ }^{3}$ Ohnsorge and Ooomes (2005).
} 
Given that, as mentioned above, foreign currency has served all standard money functions in Tajikistan from the beginning of transition, perhaps it is worth including foreign cash holdings in the definition of money when examining the relationship between money growth and inflation. This expanded version of broad money will eliminate the effect of somoni volatility on the choice of currency holdings: dollarization and dedollarization will merely represent portfolio shifts. Expanding the broad money definition further and employing more stable and broader variables would help better understand inflation; this data is not, however, available in Tajikistan. ${ }^{4}$

Figure 1. Money Growth and Inflation (annual \% change, e.o.p, unless otherwise indicated)

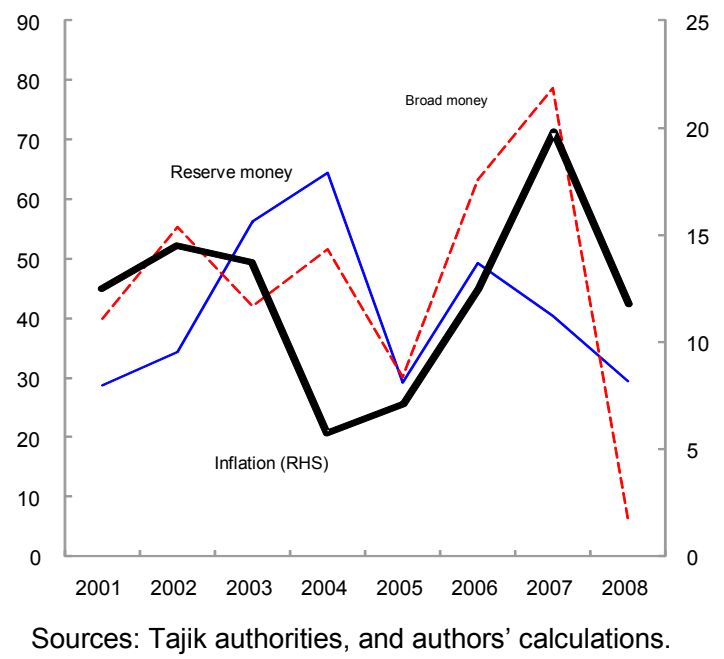

Figure 2. National Bank of Tajikistan Refinancing Rate and Commercial Bank Lending Rate (in percent)

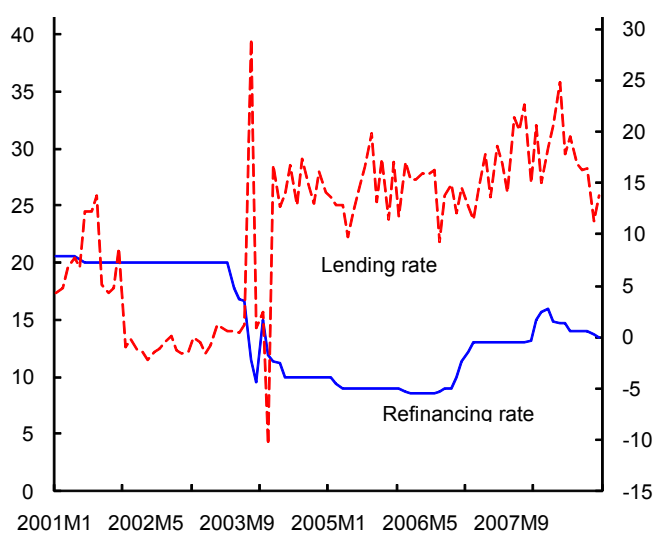

Source: Tajik authorities.

In conventional macroeconomic models, the interest rate channel is considered a principal transmission vehicle, where an increase in nominal interest rates by the central bank should translate into an increase in real interest rate and the cost of capital, affecting aggregate demand and inflation. This said, while a central bank and basic financial system exist in Tajikistan, the coexistence of shallow markets, the practice of directed credit provision, and weak enforcement of prudential standards reduces the impact of this transmission channel. The policy interest rate pass-through to market rates does not play a significant role in Tajikistan and there is an obvious disconnect between National Bank of Tajikistan (NBT) and commercial bank rates (Figure 2). Rather than following the NBT's decisions on interest rates, and due to the high level of dollarization, banks set interest rates according to supply of, and demand for, their own funds. And, given the scarcity of funding, high concentration, and a low level of competition, interest rates and banking spreads have been historically very high. ${ }^{5}$ In the past, the NBT adjusted rates with a lag, making the adjustment rather symbolic.

\footnotetext{
${ }^{4}$ For Russia, such data were collected by estimating the amount of currency on hand in 1991 and then adding net foreign sales by booths/banks, net withdrawals from foreign deposits, and foreign exchange for travel and shuttle trade (Ibid).

${ }^{5}$ The high deposit-lending spreads are driven by three main factors-limited credit risk assessment and mitigation mechanisms, weak competition, and deficiencies in the tools and infrastructure for liquidity management (2008, IMF).
} 
More recently — starting in 2009 - the NTB has set the interest rate on the basis of a small spread above inflation. Possible explanations for this strategy could be that the NBT believed that keeping interest rates at superficially low (negative) levels supported economic activity, given the aforementioned constraints, including dollarization, and thus treated interest rates as a "growth" policy tool. ${ }^{6}$ Also, given its weak financial position, the NBT can hardly afford offering interest rates close to market rates, and thus can only offer small quantities of instruments, igniting little interest from banks.

The exchange rate channel is also an essential element in open-economy macro models, mostly as it relates to an interest rate channel, where via an uncovered interest parity condition interest rate differentials lead to exchange rate movements. In Tajikistan, this aspect of the transmission channel is obviously not at work, given the shallowness of the financial system and poor investment climate. Rather, the exchange rate channel could be expected to be a function of the current account, determining the extent of the pass-through to prices. The effect of exchange rate changes on the domestic price of imported goods and overall inflation depends on the 1) import share, 2) magnitude of the fluctuations and their timing, 3) presence of a de facto pegging of prices to the (main) exchange rate, and 4) structural characteristics of the economy, including the level of dollarization and remittance flows. Tajikistan's small open economy, characterized by a high imports-to-GDP ratio (estimated at 62 percent of 2008 GDP), a consumption basket with a large import content, and a high level of dollarization and remittances, suggests that a significant pass-through effect from the exchange rate to prices should be observed. In an event of a sudden large devaluation, the effect on inflation could be significant, as low domestic production capacity (not least due to energy shortages) would preclude a quick switch to import substitution, as has occurred in other countries of the Commonwealth of Independent States.

As stated, both of the aforementioned transmission channels should be sensitive to the degree of dollarization. ${ }^{7}$ In Tajikistan, both payments and financial dollarization-defined as a widespread use of foreign currencies as a store of value and in (large cash) transactions - is present. While dollarization played a major stabilizing role in transition economies and helped in remonetization (i.e., growth in foreign exchange deposits), it reduces central banks' influence on monetary aggregates, distorts the link between domestic money and inflation,

\footnotetext{
${ }^{6}$ The lack of tradable government securities constrains monetary policy implementation and banks' liquidity management. In the absence of domestic financing requirements, the ministry of finance has not issued securities since 2001. The NBT certificates were first issued in 2003 but the NBT's insolvency discourages larger placements and market-based pricing. The resultant lack of freely transferable collateral drastically limits the use of repos and holds back the development of an interbank money market. These constraints, the lack of standing facilities at the NBT, and payment system's deficiencies, heighten banks' incentives to hold ample idle liquidity (Ibid). There is no secondary market for government debt (the majority is held by the central bank) and the interbank market is inactive.

${ }^{7}$ Loan dollarization stood at 60 percent at end-2008. The main driving factor appears to be the evolving currency composition of banks' funding, which is increasingly skewed toward the foreign currency.
} 
leads to mismatches in assets and liabilities of the financial entities, and changes the timing and effects of shocks. Thus, in many countries with a high level of dollarization, the exchange rate channel becomes a dominating one. To reduce the exchange rate influence on inflation, from 2006 until about the beginning of 2009, the NBT maintained a de facto exchange rate peg to a dollar - a policy that was sustainable in light of large inflows of remittances, foreign direct investment, and aid.

Finally, a narrow credit channel is defined by the provision of credit to the private sector guided by the state of the monetary policy. This relates more to the quantity of credit rather than its price (although, of course, they are interrelated). An increase in reserve requirements (a contractionary monetary policy) should lead to a reduction in credit available and a subsequent reduction in demand and inflation. In Tajikistan, however, despite rapid growth in deposits and lending ${ }^{8}$, the supply of loanable funds is still very limited (not least due to the low-income nature of economy, distrust in the banking system, and the population's limited access to financial services). Also, banks' high excess reserves (for the lack of good investment opportunities, inefficiencies in the payments system, and as insurance) rendered banks rather indifferent to monetary policy decisions.

\section{EMPIRICAL INVESTIGATION}

\section{Vector Error Correction Model (VECM)}

Based the discussion above, inflation in Tajikistan can be estimated using the VECM, which can be specified as:

$$
\Delta x_{t}=\phi(L) \Delta x_{t}+x_{t}^{\prime} \delta+z_{t} \gamma+\varepsilon_{t}
$$

where $x_{t}=\left(p_{t}, m_{t}, y_{t} e_{t}, p_{t}^{*}\right)$ is a vector of variables that includes CPI $\left(p_{t}\right)$, broad money $\left(m_{t}\right)$, real GDP $\left(y_{t}\right)$, nominal effective exchange rate $\left(e_{t}\right)$ and foreign prices $\left(p_{t}^{*}\right)$ proxied by world GDP deflator. $Z$ is a vector of control and exogenous variables such seasonal dummies and (if necessary) time trend. $\Delta$ indicates taking the first difference, and $\phi(L)$ is the coefficients matrix (matrices) for lag operators $L . \delta$ is the co-integration vector(s) capturing the long-run relation among the variables in the system. The lag length for the VECM is selected to be 2 based on the Akaike Information Criterion (AIC).

\footnotetext{
${ }^{8}$ At end-2008, commercial banks' credit constituted only 47 percent of their assets. Lending has been primarily short term in nature (between 1 and 3 years) driven by the short-term maturity of deposits as well as risk aversion. Loan dollarization stood at 56 percent, and the majority of lending has been directed towards agricultural lending.
} 


\section{Unit Root Tests}

To determine the order of integration of the variables, we test the null hypothesis of a unit root on the above variables. The results of the augmented Dickey-Fuller (ADF) t-test are reported in Table 1. The number of lags included in the ADF tests is based on the AIC. The first column shows the values of the ADF t-test from a regression of the left-hand side variable on this variable lagged one period and on its first difference, while the second column shows the ADF t-test for the same regression but in first difference. The test clearly shows that the variables included are integrated of order one, I(1), except for foreign prices, which is I(2). The VECM, therefore, uses the level of variables, except for foreign prices, which enters the model as a first difference.

Table 1. Augmented Dickey-Fuller Unit Root Tests ${ }^{1 /}$

\begin{tabular}{lcc}
\hline & Level & First Difference \\
\hline CPI & $2.69^{*}$ & $5.95^{* * *}$ \\
Broad money & 1.61 & $6.52^{* * *}$ \\
Real GDP & 2.44 & $5.24^{* * *}$ \\
Nominal exchange rate & 1.98 & $4.20^{* * *}$ \\
Interest rate & 1.69 & $4.72^{* * *}$ \\
Foreign prices & 1.73 & 1.63 \\
\hline
\end{tabular}

${ }^{1 /}$ T-statistics, null hypothesis: unit root.

* indicates 10 percent, ${ }^{* *}$ indicates 5 percent, and ${ }^{* * *}$ indicates 1 percent significance.

\section{Co-Integration Tests}

The next step in the VECM is to determine the number of co-integration relations among these I(1) variables. The results of a co-integration test (the Johansen test, Table 2) suggest one co-integration vector, shown in equations (2) and (3). Equation (3) shows an unrestricted co-integration relation whereas the coefficients on $p_{t}$ and $m_{t}$ are set to -1 and 1 in equation (3) as to represent a theoretical money demand equation. Table 3 shows a spate test for the second normalization, i.e., the unity of the coefficient on $\mathrm{m}_{\mathrm{t}}$. This test clearly rejects the unity hypothesis on the coefficient on money.

Unrestricted co-integration relation:

$$
\hat{p}=0.09 m-1.11 y+0.21 e+3.66 \Delta p^{*}
$$

Restricted co-integration relation:

$$
\hat{p}=m-1.28 y+5.33 e+6.11 \Delta p^{*}
$$

The estimated long-run coefficients of the restricted co-integration vector are mostly significant and also have the anticipated signs. The income elasticity or transaction demand for money is larger than unity and significant. This could be explained by monetization, e.g., a decrease in barter transactions as the country grew richer. Inflation is also found to be 
sensitive to the nominal effective exchange rate. The nominal exchange rate enters the model as somoni/U.S. dollar, thus, equation (2) indicates that an increase in the rate of depreciation would lead to an increase in the price level, as one would expect in a small open economy like Tajikistan. Finally, international prices are also found to have a large and significant long-run impact on Tajik price level. The unrestricted co-integration relation is also associated with a significant adjustment coefficient.

Table 2. Johansen Co-Integration Tests

\begin{tabular}{|c|c|c|c|c|}
\hline \multicolumn{5}{|c|}{ Unrestricted Co-integration Rank Test (Trace) } \\
\hline $\begin{array}{c}\text { Hypothesized } \\
\text { No. of CE(s) }\end{array}$ & Eigen Value & Trace Statistic & $\begin{array}{c}1 \% \text { Critical } \\
\text { Value }\end{array}$ & P-Value \\
\hline None & 0.86 & 120.79 & 77.82 & $0.00^{*}$ \\
\hline At most 1 & 0.46 & 47.05 & 54.68 & 0.06 \\
\hline At most 2 & 0.29 & 23.78 & 35.46 & 0.21 \\
\hline At most 3 & 0.24 & 10.62 & 19.94 & 0.24 \\
\hline At most 4 & 0.01 & 0.43 & 6.63 & 0.51 \\
\hline \multicolumn{5}{|c|}{ Unrestricted Co-integration Rank Test (Maximum Eigen value) } \\
\hline $\begin{array}{c}\text { Hypothesized } \\
\text { No. of CE(s) }\end{array}$ & Eigen Value & $\begin{array}{c}\text { Max-Eigen } \\
\text { Statistic }\end{array}$ & $\begin{array}{c}1 \% \text { Critical } \\
\text { Value }\end{array}$ & P-Value \\
\hline None & 0.86 & 73.74 & 39.37 & $0.00^{*}$ \\
\hline At most 1 & 0.46 & 23.27 & 32.72 & 0.16 \\
\hline At most 2 & 0.29 & 13.16 & 25.86 & 0.44 \\
\hline At most 3 & 0.24 & 10.19 & 18.52 & 0.20 \\
\hline At most 4 & 0.01 & 0.43 & 6.63 & 0.51 \\
\hline
\end{tabular}

* Denotes rejection of the hypothesis at the 0.01 level.

The weak exogeneity tests on the adjustment coefficients are shown in Table $4 .^{9}$ The test clearly indicates that broad money, real GDP, interest rate, and exchange rate are weakly exogenous to this co-integration relation, suggesting that the deviation from the long-run relation affects inflation. The convergence to the long-run equilibrium occurs at a speed of 33 percent per quarter: one-third of the discrepancy between inflation and its equilibrium is corrected in each period.

\footnotetext{
${ }^{9}$ For definition of and discussion about exogeneity, see Engle, Hendry, and Richard (1993).
} 
Table 3. Model Restriction and Weak Exogeneity Tests

\begin{tabular}{cccccc}
\hline Test & $\begin{array}{c}\text { Hypothesized } \\
\text { No. of CE(s) }\end{array}$ & $\begin{array}{c}\text { Restricted } \\
\text { Log- } \\
\text { Likelihood }\end{array}$ & $\begin{array}{c}\text { LR } \\
\text { Statistic }\end{array}$ & $\begin{array}{c}\text { Degrees of } \\
\text { Freedom }\end{array}$ & Probability \\
\hline $\mathrm{B}(1,2)=1$ & 1 & 589.64 & 15.76 & 1 & 0.00 \\
$\mathrm{~A}(1,1)=0$ & 1 & 579.02 & 37.00 & 1 & 0.00 \\
$\mathrm{~A}(2,1)=0$ & 1 & 597.15 & 0.75 & 1 & 0.39 \\
$\mathrm{~A}(3,1)=0$ & 1 & 597.43 & 0.18 & 1 & 0.67 \\
$\mathrm{~A}(4,1)=0$ & 1 & 536.71 & 0.07 & 1 & 0.79 \\
\hline
\end{tabular}

\section{The Forecast}

Using the VECM explained above, it is interesting to look at the forecast dynamic of the model. The first step is to determine the model's ability to forecast inflation by conducting an ex-post, out-of-sample forecast. To do that, we use 1999Q1-2007Q4 data to derive our estimates, and then conduct a forecasting exercise for 2008Q1-2009Q2 (Figure 3). A quick look at actual versus forecasted values shows that forecasted inflation decreases faster than actual values during the second half of 2008. While actual inflation mostly tends to mimic the trend of forecasted values, during some periods, actual values are outside of the confidence bands of forecasted inflation. This observation could be a direct result of a small sample, which weakens the forecasting ability of our model. We, nonetheless, conduct a forecasting exercise using this model and compare the results with another widely used model.

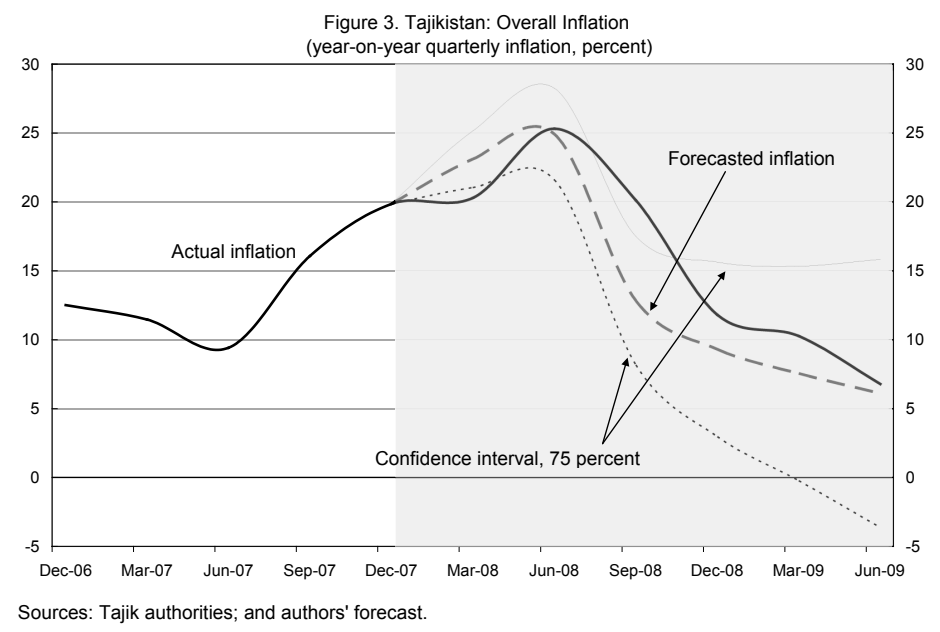

Using the IMF World Economic Outlook forecast for exogenous international prices, a dynamic forecast for 2009Q3-2010Q4 is conducted. The outcome of this forecast is plotted in Figure 4. The model shows that inflation in Tajikistan is likely to increase by to 6 percent by end-2009 (or two percentage points above the latest observation of end-September). 
In 2010, CPI inflation is likely to follow a downward trend through the first quarter, driven by the lagged impact of international prices. Average inflation in 2010 is likely to be around 7.5 percent. Toward the end of the year, CPI inflation is projected to pick up slightly to 10.6 percent. This trend follows the trend in international prices and the projected depreciation of the Tajik currency in 2010.

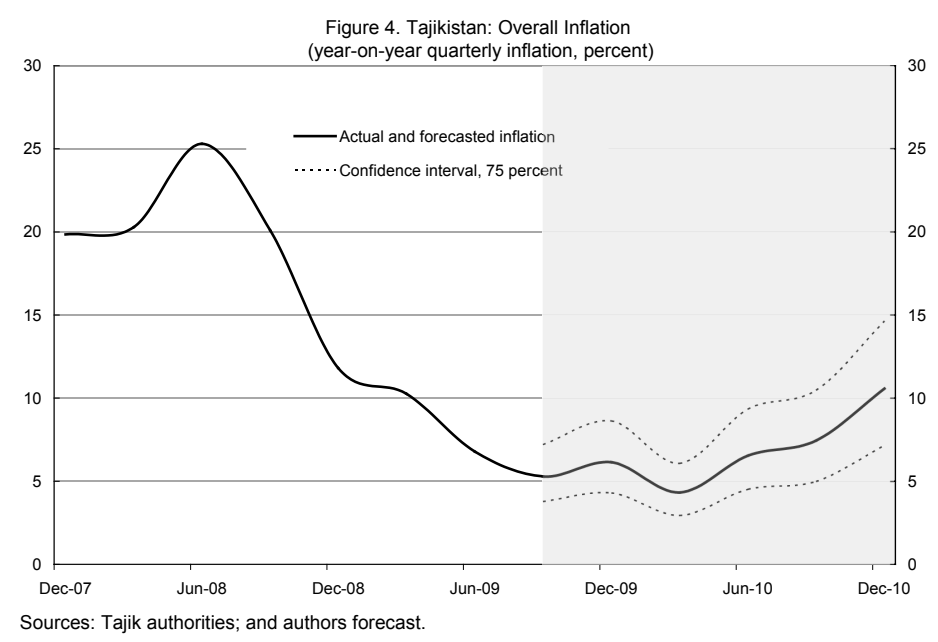

\section{Autoregressive Moving Average Model (ARMA)}

A second approach we employ to forecast inflation, and then compare results from the VECM exercise, is the ARMA model, where short-term fluctuations from the original series are removed. Figure 6 plots four different measures of inflation: overall year-on-year CPI inflation, 3-month average year-on-year CPI inflation, 12-month average year-on-year CPI inflation, and core CPI inflation. While averaging inflation clearly reduces short-term fluctuations, average CPI tends to be lagged relative to the original series. 12-month average inflation shows significant delay relative to original inflation, suggesting that this inflation does not track developments in actual inflation in a timely manner. The delay of the 3-month average inflation to actual inflation is much smaller. Thus, we chose to focus on the 3-month average inflation in our forecast ${ }^{10}$. Core CPI inflation, which excludes food and fuel, is also plotted in Figure 6. The advantage of using this measure, rather than the overall CPI inflation, is to reduce the impact of the external environment on domestic prices. One limitation is that the time series for such a measure is shorter than the overall inflation time series.

\footnotetext{
${ }^{10}$ While we focus on the 3-month inflation average to reduce short-term noise in the date, we have also used year-on-year CPI inflation to estimate ARMA models. These models performed less robustly than those with 3-month inflation average.
} 


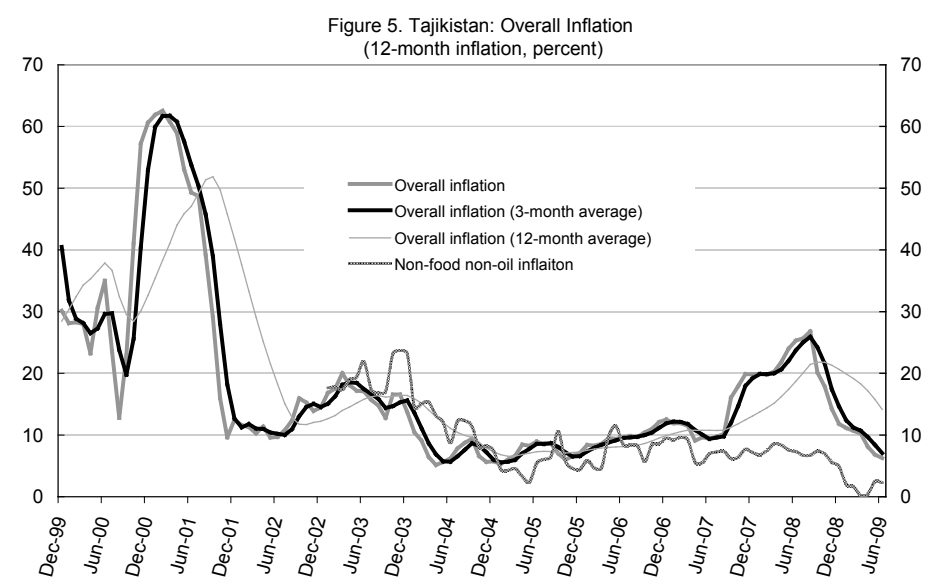

Sources: Tajik authorities; and authors' calculations.

The $\operatorname{ARMA}(p, q)$ model forecasts inflation at period $t$ as a linear projection of (i) inflation from period $t-1$ to $t-p$, autoregressive (AR) part, and (ii) white noise from period $t$ to $t-q$, moving average (MA) part. The advantages of this model are its simple structure, minimum data requirements, and reasonable forecasting outcome. Given an assumption that inflation is a stationary process, an ARMA process can be written as:

$$
\pi_{t}=\beta_{\mathrm{O}}+\sum_{i=1}^{p} \beta_{i} \pi_{t-i}+\varepsilon_{t}+\sum_{j=1}^{q} \theta_{j} \varepsilon_{t-j}
$$

The parameters in equation (4) are estimated using the Maximum Likelihood Estimates (MLE) method, assuming that error term $(\varepsilon)$ is white noise and follows a normal distribution. To determine the number of autoregressive terms $(p)$ and moving average terms $(q)$, three steps are applied. First, is to test autocorrelation of residuals using the Breusch-Godfrey Lagrange Multiplier test. Second, the distribution of residuals is tested using the Jarque-Bera test for normal distribution. The two steps verify whether the specification of the ARMA model is consistent with the assumptions of the MLE: the error term is white noise and follows a normal distribution. The third step is to pick a model with the smallest value of the Schwartz Information Criterion (SIC) and AIC among the models that are qualified by the first two steps.

Table 5 summarizes 42 different ARMA models based on different $\mathrm{p}$ and $\mathrm{q}$ values, and shows that ARMA $(2,2)$ - two autoregressive terms and two moving average terms - and $\operatorname{ARMA}(5,5)$ are the best models to forecast inflation in Tajikistan. $\operatorname{ARMA}(2,2)$ shows the lower SIC value where $\operatorname{ARMA}(5,5)$ is associated with the lower AIC value. Both of these models are consistent with the assumptions of the MLE. The following analysis is based on $\operatorname{ARMA}(2,2)$. The results of the $\operatorname{ARMA}(5,5)$ are discussed in the appendix. 
Table 4. Main Statistics of Various ARMA Models, 1999-2009

\begin{tabular}{|c|c|c|c|c|c|c|c|c|c|c|c|c|c|}
\hline & Ajusted R2 & SE 1/ & $\mathrm{AIC}$ & SIC & LM test 2/ & Jarque-Bera 3/ & & Ajusted R2 & SE 1/ & AIC & $\mathrm{SIC}$ & LM test $2 /$ & Jarque-Bera $3 /$ \\
\hline $\operatorname{ARMA}(0,1)$ & 0.75 & 7.30 & 6.83 & 6.90 & 0.00 & 0.00 & $\operatorname{ARMA}(1,1)$ & 0.99 & 1.00 & 2.88 & 3.00 & 0.00 & 0.00 \\
\hline $\operatorname{ARMA}(0,2)$ & 0.92 & 4.17 & 5.73 & 5.82 & 0.00 & 0.00 & $\operatorname{ARMA}(1,2)$ & 0.99 & 0.75 & 2.30 & 2.45 & 0.00 & 0.00 \\
\hline $\operatorname{ARMA}(0,3)$ & 0.96 & 2.74 & 4.90 & 5.01 & 0.00 & 0.00 & $\operatorname{ARMA}(1,3)$ & 0.99 & 0.63 & 1.99 & 2.17 & 0.30 & 0.01 \\
\hline $\operatorname{ARMA}(0,4)$ & 0.98 & 2.10 & 4.38 & 4.51 & 0.00 & 0.00 & $\operatorname{ARMA}(1,4)$ & 0.99 & 0.64 & 2.05 & 2.29 & 0.21 & 0.02 \\
\hline $\operatorname{ARMA}(0,5)$ & 0.99 & 1.42 & 3.60 & 3.75 & 0.00 & 0.10 & $\operatorname{ARMA}(1,5)$ & 0.99 & 0.70 & 2.20 & 2.42 & 0.27 & 0.00 \\
\hline $\operatorname{ARMA}(0,6)$ & 0.99 & 1.31 & 3.44 & 3.63 & 0.00 & 0.74 & $\operatorname{ARMA}(1,6)$ & 0.99 & 0.64 & 2.04 & 2.30 & 0.00 & 0.50 \\
\hline $\operatorname{ARMA}(2,1)$ & 0.99 & 0.77 & 2.36 & 2.51 & 0.00 & 0.00 & $\operatorname{ARMA}(3,1)$ & 0.99 & 0.72 & 2.25 & 2.43 & 0.00 & 0.00 \\
\hline$A R M A(2,2)$ & 0.99 & 0.59 & 1.84 & 2.01 & 0.38 & 0.53 & $\operatorname{ARMA}(3,2)$ & 0.99 & 0.59 & 1.84 & 2.04 & 0.00 & 0.48 \\
\hline $\operatorname{ARMA}(2,3)$ & 0.99 & 0.60 & 1.85 & 2.05 & 0.14 & 0.42 & $\operatorname{ARMA}(3,3)$ & 0.99 & 0.60 & 1.90 & 2.12 & 0.20 & 0.99 \\
\hline $\operatorname{ARMA}(2,4)$ & 0.99 & 0.59 & 1.85 & 2.08 & 0.40 & 0.26 & $\operatorname{ARMA}(3,4)$ & 0.99 & 0.58 & 1.84 & 2.09 & 0.00 & 0.41 \\
\hline $\operatorname{ARMA}(2,5)$ & 0.99 & 0.58 & 1.82 & 2.07 & 0.75 & 0.15 & $\operatorname{ARMA}(3,5)$ & 0.99 & 1.12 & 3.16 & 3.43 & 0.00 & 0.68 \\
\hline $\operatorname{ARMA}(2,6)$ & 0.99 & 0.66 & 2.11 & 2.38 & 0.00 & 0.06 & $\operatorname{ARMA}(3,6)$ & 0.99 & 0.59 & 1.89 & 2.19 & 0.02 & 0.93 \\
\hline $\operatorname{ARMA}(4,1)$ & 0.99 & 0.68 & 2.14 & 2.34 & 0.00 & 0.00 & $\operatorname{ARMA}(5,1)$ & 0.99 & 0.63 & 2.01 & 2.23 & 0.00 & 0.00 \\
\hline $\operatorname{ARMA}(4,2)$ & 0.99 & 0.59 & 1.85 & 2.07 & 0.00 & 0.44 & $\operatorname{ARMA}(5,2)$ & 0.99 & 0.57 & 1.81 & 2.06 & 0.03 & 0.89 \\
\hline $\operatorname{ARMA}(4,3)$ & 0.99 & 0.59 & 1.88 & 2.13 & 0.00 & 0.88 & $\operatorname{ARMA}(5,3)$ & 0.99 & 0.58 & 1.86 & 2.14 & 0.00 & 0.57 \\
\hline $\operatorname{ARMA}(4,4)$ & 0.99 & 0.58 & 1.86 & 2.13 & 0.00 & 0.16 & $\operatorname{ARMA}(5,4)$ & 0.99 & 0.57 & 1.83 & 2.13 & 0.08 & 0.56 \\
\hline $\operatorname{ARMA}(4,5)$ & 0.99 & 0.59 & 1.88 & 2.18 & 0.00 & 0.08 & $\operatorname{ARMA}(5,5)$ & 0.99 & 0.54 & 1.71 & 2.04 & 0.89 & 0.20 \\
\hline $\operatorname{ARMA}(4,6)$ & 0.99 & 0.63 & 2.03 & 2.35 & 0.00 & 0.31 & $\operatorname{ARMA}(5,6)$ & 0.99 & 1.23 & 3.35 & 3.64 & 0.00 & 0.00 \\
\hline $\operatorname{ARMA}(6,1)$ & 0.99 & 0.63 & 2.01 & 2.26 & 0.00 & 0.00 & & & & & & & \\
\hline $\operatorname{ARMA}(6,2)$ & 0.99 & 0.55 & 1.74 & 2.02 & 0.00 & 0.71 & & & & & & & \\
\hline $\operatorname{ARMA}(6,3)$ & 0.99 & 0.53 & 1.68 & 1.98 & 0.01 & 0.69 & & & & & & & \\
\hline $\operatorname{ARMA}(6,4)$ & 0.99 & 0.57 & 1.84 & 2.17 & 0.00 & 0.10 & & & & & & & \\
\hline $\operatorname{ARMA}(6,5)$ & 0.99 & 1.25 & 3.38 & 3.67 & 0.00 & 0.00 & & & & & & & \\
\hline $\operatorname{ARMA}(6,6)$ & 0.99 & 1.24 & 3.38 & 3.69 & 0.00 & 0.00 & & & & & & & \\
\hline
\end{tabular}

Sources: Tajik authorities; and authors' estimates.

$1 /$ Standard error of regressions.

2/ Breusch-Godfrey Serial Correlation Lagrange Multiplier Test, p-value to reject the null hypothesis: no serial correlation.

3/ Jaque-Bera Test Statistics for Normality, p-value to reject the null hypothesis: normal distribution. 
The fit of the estimated ARMA model to actual inflation during the sample period (January 1999-October 2008) is striking. The adjusted $R^{2}$ suggests that over 99 percent of the fluctuations in inflation can be explained by the estimated ARMA model consisting of only lags of inflation and residuals. Also, the standard error of regression is less than one percentage point, implying that the 95 percent confidence interval of the model during the sample period is at most plus/minus 1.5 percentage points from the inflation based on the estimated model. This is surprisingly small compared to average inflation during the sample period. To test the forecasting ability of the model, $\operatorname{ARMA}(2,2)$ model is estimated using a smaller sample (through June 2008); the result is then used to produce a forecast for July 2008-June 2009 ( Figure 7). Actual inflation stays within the 75 percent confidence interval during the simulation period and tracks forecasted inflation quite well. The ARMA model ex-post, out-of-sample forecast clearly outperforms the forecast of the VECM, possibly due to the limited sample used in the VECM.

Figure 8 shows forecasted inflation for 2009 and 2010. The results indicate that (i) 3-month average inflation will be at 6 percent by end-2009; and (ii) inflation will gradually increase during 2010 to reach 12 percent in December 2010, similar to the result obtained by the VECM.
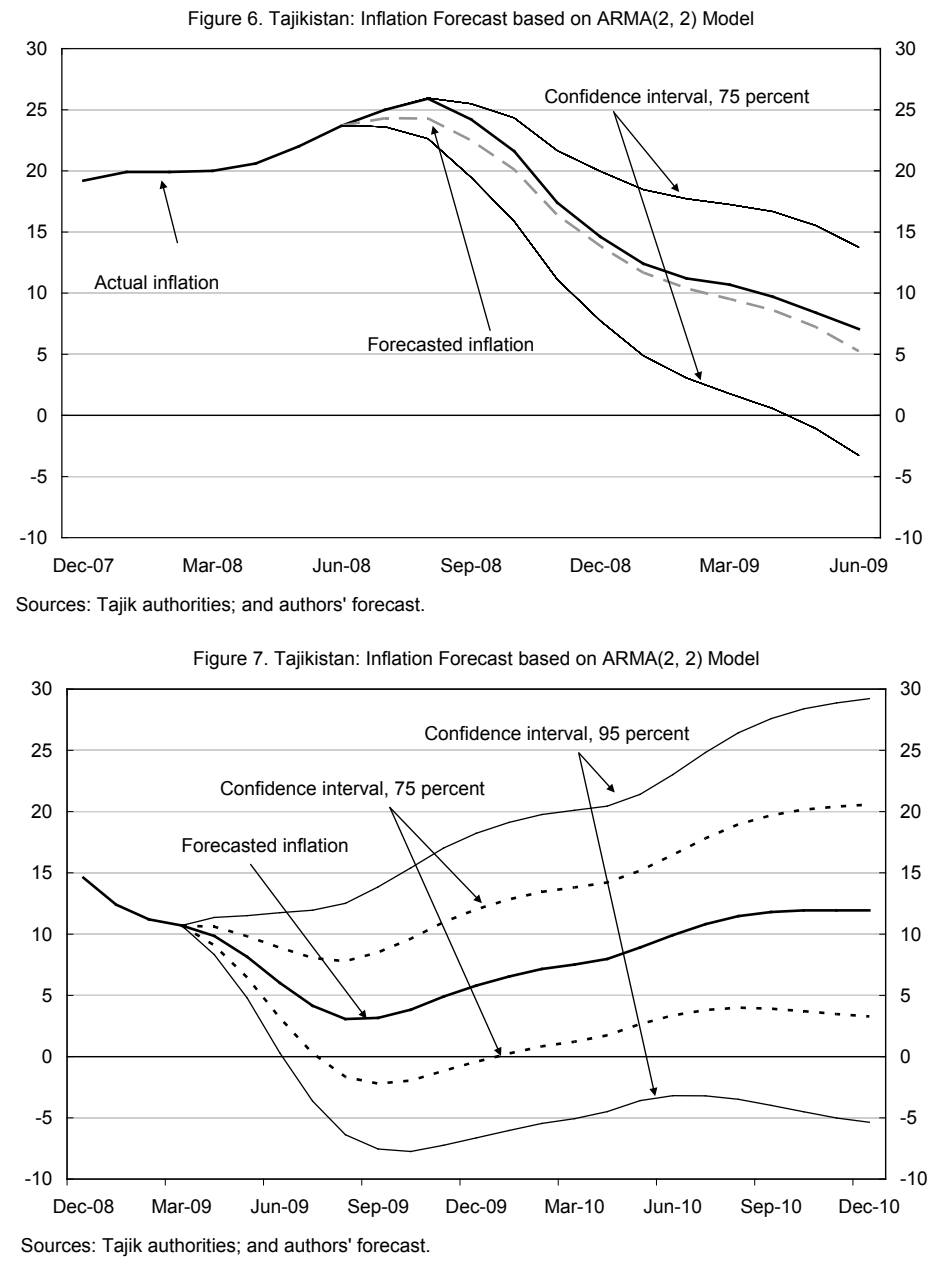


\section{SUMMARY AND CONSIDERATIONS}

\section{Empirical findings}

- Inflation dynamics in Tajikistan were tested using the VECM. Broad money growth is found to be highly significant in determining inflation in both the short and long terms. Real GDP is found to be an important determinant of inflation, especially in the long run. The policy interest (refinancing) rate does not have influence on inflation as it is decoupled from the market rate and does not affect financial decisions of economic agents and the supply of credit. The exchange rate has a strong impact on prices, supported by evidence from other economies with a large degree of dollarization. While a rather steady depreciation of the somoni has been observed since 2001, at a time when inflation was on a sharp downward path (until international prices spiked in 2008), this could be attributed to other factors, such as stabilization of the economy and a pick-up in domestic production. The domestic price level is also found to be significantly affected by the movement in international prices. Finally, the model estimates the magnitude of the error correction term at 33 percent; thus any disequilibrium in the price level is likely to be eliminated within nine months.

- $\quad$ The paper uses the VECM and ARMA to forecast inflation. Both models show remarkable forecasting explanatory power during the sample period. End-period inflation is projected to reach 6-9 percent in 2009 and increase to $10.5-12$ percent in 2010. These results are consistent with the observed exchange rate depreciation in 2009, which is expected to carry over to 2010 as well. 


\section{Current State of Monetary Policy Management}

Empirical results suggest that, at present, the NBT's ability to control inflation is quite limited. Available instruments, such as reserve requirements and a refinancing rate, have proven to be ineffective. With respect to the latter, most banks comply with the reserve requirements of 9 and 7 percent for non-resident and resident deposits, respectively. In addition, excess liquidity has been observed in the banking system prior to the 2009 financial crisis. As discussed above, the refinancing rate has not been an influential tool in directing money supply. The only effective instrument currently employed by the NBT to control the money supply is transactions with foreign currencies. Therefore, to facilitate monetary policy execution and financial market development, the NBT could greatly benefit from improving existing instruments, and developing new ones.

\section{Steps to Improve the Monetary Policy Toolkit}

- $\quad$ Strengthen the interest rate channel: At this stage, it appears to be most effective to strengthen the existing monetary policy transmission channel - the interest rate channel. Adjusting policy interest rates to a level that is attractive to financial market participants will help manage credit provision to the economy (broad money), and influence aggregate demand and inflation over time ${ }^{11}$. In addition, the NBT should strengthen its financial position and improve transparency so as to become a trustworthy counterpart to the private sector.

- $\quad$ Ensure that reserve requirements become an effective instrument of monetary policy: While not a day-to-day money supply management tool, reserve requirements can be a powerful prudential tool if they are set in way that reflects the current state of monetary conditions and developments in the banking system. The NBT changed reserve requirement regulations on several occasions during the past two years, and they remain differentiated. ${ }^{12}$ In the future, it will be important that the treatment of both types of deposits is unified and compliance with the requirement is strictly enforced.

- $\quad$ Resume regular operations with tradable securities (e.g., government bonds or central bank bills): These securities should be used to mop up excess liquidity, and can also serve as collateral for bank borrowing. A reference yield curve would gradually be established, facilitating the pricing of credit risk in the private sector and

\footnotetext{
${ }^{11}$ The NBT's plan to set up a deposit standing facility is a step in this direction.

${ }^{12}$ A large share of nonresident deposits is reportedly deposited abroad, but this could be easily reversed. Moreover, the exclusion creates an incentive for banks to book deposits as nonresident deposits (this may partly explain the exceptional increase in nonresident deposits in the first half of 2007 and subsequent sharp decline after the exclusion was reversed).
} 
development of a broader securities market. ${ }^{13}$ Also, promotion of somonidenominated medium- and long-term securities (both private and government) will increase investment opportunities, hedge foreign exchange exposure, and remove structural liquidity. This, admittedly, will take time in Tajikistan.

- $\quad$ Encourage financial deepening: Despite the recent rapid growth in credit and deposits, Tajikistan's banking sector remains rudimentary, and economic agents still prefer to rely on cash transactions. Given the population's preference for holding foreign currency, banks could help promote the deposit of remittances in the banking system, and the NBT could help foster competition. New products, such as payment cards, could reduce the costs of cash handling and make it possible for remittance beneficiaries to hold deposit accounts. ${ }^{14}$ These initiatives would also help the authorities have a better grasp of the "true" state of the monetary base (including foreign holdings) and improve monetary policy management.

- $\quad$ Strengthen the bank lending channel: The authorities have made progress in implementing financial sector reforms, including by encouraging foreign bank entry into the market. Nonetheless, to strengthen the bank lending channel, greater efforts are needed to strengthen corporate accounting standards and governance, bankruptcy procedures, use of collateral, and creditor rights.

\footnotetext{
${ }^{13} 2008$, IMF.

${ }^{14}$ It is indispensable to develop awareness campaigns, concrete education mechanisms, and specific incentives to encourage remittance recipients to use these products. The NBT could foster competition among money transfer operators by increasing market transparency (e.g., publishing comparative data on various pricing and service alternatives offered by banks and other paying agents).
} 


\section{References}

Bovin, J. and Giannoni, M. (2002), “Assessing Changes in the Monetary Transmission Mechanism: a VAR Approach”, FRBNY Economic Policy Review (New York: Federal Reserve Bank of New York).

Dabla-Norris, E. and Floerkemeier, H. (2006), "Transmission Mechanisms of Monetary Policy in Armenia: Evidence from VAR Analysis”, IMF Working Paper 06/248 (Washington: International Monetary Fund).

Engle, R., Hendry, D. F., and Richard, J.F. (1983). "Exogeneity”, Econometrica, 51: pp. 277-304.

Harvàth, B. and Maino, R. (2006), "Monetary Transmission Mechanisms in Belarus", IMF Working Paper 06/246 (Washington: International Monetary Fund).

Hendry, D., Krolzig, M., 2005, “The Properties of Automatic Gets Modeling”, The Economic Journal, Volume 115, (March), pp. C32-61.

Ireland, P. (2005), “The Monetary Transmission Mechanism”, FRBB Working Paper (Boston: Federal Reserve Bank of Boston).

Kuttner, K. and Mosser, C. (2002), “The Monetary Transmission Mechanism: Some Answers and Further Questions”, FRBNY Economic Policy Review (New York: Federal Reserve Bank of New York).

Maliszewski, W. (2003), "Modeling Inflation in Georgia”, IMF Working Paper 03/212 (Washington: International Monetary Fund).

Mankiw, G. (1992), Macroeconomics, Worth Publishers, Inc., New York, New York.

Ohnsorge, F. and Oomes, N. (2005), "Money Demand and Inflation in Dollarized Economies: The Case of Russia”, IMF Working Paper 05/144 (Washington: International Monetary Fund).

Rebucci, A. (2000), "Inflation and Exchange Rate Dynamics", Tajikistan: Recent Economic Developments, IMF Staff Report SM/00/5 (Washington: International Monetary Fund).

Stock, J. and Watson, M. (2001), "Vector Autoregressions", Journal of Economic Perspectives, Vol. 15, No.4, pp. 101-115. 
Tashrifov, Y (2008), “The Design of Monetary Policy in a Small Transitional Open Economy: the Case of Tajikistan", Zagreb International Review of Economics and Business, Vol. 11, No.1, pp. 13-36.

Taylor, J. (1995), "The Monetary Transmission Mechanism: An Empirical Framework", Journal of Economic Perspectives, Vol. 9, No. 4 (Fall), pp. 11-26.

Wickens, M. and Motto, R.(2001), "Estimating Shocks and Impulse Response Functions", Journal of Applied Econometrics, Vol. 16, no. 3, pp. 371-387.

Tajikistan-Financial Sector Sustainability Assessment, 2008 (Washington: International Monetary Fund). 